\title{
HOXB1 Gene
}

National Cancer Institute

\section{Source}

National Cancer Institute. HOXB1 Gene. NCI Thesaurus. Code C162630.

This gene is involved in the development of anterior embryonic structures and facial nerves. 